\title{
A Primer on Exporting to Barbados ${ }^{1}$
}

\author{
Christina D. Storz, Timothy G. Taylor, and Gary F. Fairchild ${ }^{2}$
}

\section{Introduction}

Every year the U.S. Department of State publishes extensive Country Commercial Guides for a large number of countries. These guides provide a great deal of information useful to individuals interested in developing exports markets either through direct exports or through direct foreign investment. This paper provides an abridged version of the Country Commercial Guide for Barbados as well as supplemental information of direct relevance to agribusiness firms. It is hoped that the information contained in this report provides a useful starting point for individuals interested in exploring export or investment opportunities in Barbados.

Note: County Commercial Guides are available for U.S. exporters from the National Trade Data Bank's CD-ROM or via the Internet. Please contact Stat-USA by telephone (1-800) STAT-USA for more information. Country Commercial Guides can be accessed via the World Wide Web at http://www.stat-usa.gov, http://www.state.gov, and http://www.mac.doc.gov. They can also be ordered as a hard copy or on diskette from the National Technical Information Service (NTIS) by telephone (1-800) 553-NTIS. American exporters seeking general export information/assistance and country-specific commercial information should contact the U.S. Department of Commerce, Trade Information Center by telephone (1-800) USA-TRADE; or by fax (202) 482-4473.

\section{Economic and Political Overview}

Barbados is an English speaking, democratic nation with national pride in its commitment to the rule of law. The open economy island is extremely dependent on imports, $40 \%$ of which come from the United States, and generates most revenue through tourism. Other sectors, such as financial services, sugar production and manufacturing also contribute to foreign exchange earnings.

Although the Barbadian economy enjoyed an average growth rate of over 3\% from 1995 to 2000, it experienced declines of $3.6 \%$ in 2001 and $0.6 \%$ in 2002. However, this slight downturn contrasted with real economic growth, moderate inflation, and a low unemployment rate from 1993 to 2000 . The economy was projected to grow between $1.5 \%$ and $2.5 \%$ in 2003, mostly due to growth in the tourism sector. The exchange rate vis-à-vis the U.S. dollar has remained unchanged $($ BDS $\$ 2.00=$ US $\$ 1.00)$ since the end of 1975.

1. This is EDIS document FE502, a publication of the Department of Food and Resource Economics, Florida Cooperative Extension Service, Institute of Food and Agricultural Sciences, University of Florida, Gainesville, FL. Published February 2005. Please visit the EDIS website at http://edis.ifas.ufl.edu.

2. Christina D. Storz, Research Assistant; Timothy G. Taylor, Professor; and Gary F. Fairchild, Professor, Department of Food and Resource Economics, Florida Cooperative Extension Service, Institute of Food and Agricultural Sciences, University of Florida, Gainesville, FL.

The Institute of Food and Agricultural Sciences is an equal opportunity/affirmative action employer authorized to provide research, educational information and other services only to individuals and institutions that function without regard to race, color, sex, age, handicap, or national origin. For information on obtaining other extension publications, contact your county Cooperative Extension Service office. Florida Cooperative Extension Service/Institute of Food and Agricultural Sciences/University of Florida/Christine Taylor Waddill, Dean. 
Much of the economic growth in Barbados has come as a result of tourism, which contributed $12 \%$ of the GDP (Gross Domestic Product) before value-added services are considered. Construction is another potential growth sector, which after a slight downturn in 2001 is expected to pick up with increased tourism-related investment projects and public sector activity. The offshore financial sector is another source of growth. Sugar production is in long-term decline, falling another 10\% in 2001. Non-sugar agriculture production has also been in a decline, falling an estimated 3.2\% in 2001.

Barbados must import to meet many of its needs, including energy, food, and most consumer products. Barbados imports over $70 \%$ of its food, over a third of which comes from the United States. Trade opportunities remain for U.S. exporters of goods, hotel and restaurant supplies, residential construction materials, and specialty agricultural and consumer products. American companies trying to break into the market would be best advised to find a local agent/distributor and prepare to make a long-term commitment to exporting to the region. Barbadian attitudes toward the United States and toward U.S. businesses are generally favorable. However, U.S. businesses face strong competition from Canada, the United Kingdom and from within the Caribbean Community and Common Market (CARICOM).

\section{Marketing U.S. Products and Services}

There are a number of factors that should be considered in exporting products to Barbados. This section provides a brief overview of many critical factors that must be considered.

\section{Establishing a Business}

Barbados laws allow the formation of several types of companies. One of these is the International Business Company (IBC). By law, a locally registered attorney is required to draft and file Articles of Incorporation. The cost of filing the application at the Corporate Affairs and Intellectual Property Office is US $\$ 375$ and US\$15 to reserve the name of the company prior to incorporation. This is mandatory. The cost of share certificates, a company seal, and other secretarial documentation required to commence operations usually does not exceed an additional US\$125. Attorney's fees are usually quoted at about US $\$ 1,500$, but fees are negotiable. Attorney's fees are normally lower for incorporation of a local company.

The Articles of Incorporation must conform to the Companies Act. It is required that an incorporator must be at least 18 years old, be of sound mind, and not have declared bankruptcy. Any number of shares may be issued. Shares must be fully subscribed and paid for before they are issued. The Corporate Affairs and Intellectual Properties Office is responsible for publishing notice of the formation of the company in the Official Gazette.

An IBC is required to obtain a license from the Ministry of International Trade and Business in order to operate. This is a fairly routine procedure and costs about US\$100. There is an annual renewal fee of US\$100.

American agricultural exporters selling to Barbados can take advantage of the following export promotion programs made available by the USDA.

- GSM-102 and GSM-103 Programs: The USDA administers export credit guarantee programs through the Commodity Credit Corporation (CCC) for commercial financing of U.S. agriculture exports. The Export Credit Guarantee Program (GSM-102) covers credit terms up to 3 years and the Intermediate Export Credit Guarantee Program (GSM-103) covers longer terms up to 10 years.

- Supplier Credit Guarantee Program (SCGP): The SCGP is designed to make it easier for exporters to sell U.S. food products overseas by ensuring short-term, open account financing. Under the security of the SCGP, U.S. exporters become more competitive by extending longer credit terms or increasing the amount of credit available to foreign buyers without increasing financial risk.

- Facility Guarantee Program (FGP): The FGP provides payment guarantees to facilitate the financing of manufactured goods and services exported from the United States to improve or 
establish agriculture-related facilities in emerging markets.

The Export-Import Bank of the United States (EXIM) also provides support for U.S. and foreign importers/exporters by assuming credit risks the private sector cannot and providing financing and insurance.

\section{Distribution / Sales Channels}

Wholesalers are the major importers, although some retailers import products directly from manufacturers, wholesalers, and retailers in the United States, Canada, and Europe. Retailers normally import directly from U.S. sources only those goods with a high turnover rate. Distribution agreements are common because manufacturers often grant countrywide or regional exclusive distribution agreements. Some companies have experienced problems collecting on accounts in a timely fashion. It is important that any prospective exporter thoroughly investigate the prospective local agent or importer.

\section{Agents / Distributors: Finding a Partner}

Although the use of an agent or distributor is not required, it is frequently the best policy. A strong local representative can place products and generate sales that otherwise might not materialize. The U.S. Department of Commerce, through the Commerical Service Section at the U.S. Embassy in Bridgetown, Barbados can help U.S. exporters find agents and distributors through the following services:

- International Partner Search (IPS): This service helps U.S. companies find local partners and licensees abroad. IPS provides a report on up to five qualified overseas agents, distributors, manufacturer's representatives, joint venture partners, licensees, franchisees, or strategic partners who have examined a U.S. company's materials and have expressed an interest in the company's products, services, or licenses, or have expressed an interest in otherwise partnering with the company. The cost for this service is US $\$ 500$ per category of business partner.
- Gold Key Service: This service surveys potential representatives or customers based on the client's requirements and pre-arranged appointments with the prospects. Fees for the Eastern Caribbean Islands served by the U.S. Commercial Service Barbados are as follows (quoted in U.S. dollars):

- Antigua -- \$350 first day, \$350 each additional day.

- Barbados -- $\$ 750$ first day, $\$ 400$ each additional day.

- Grenada -- \$350 first day, \$350 each additional day.

- Dominica -- \$350 first day, \$350 each additional day.

- St. Lucia -- \$350 first day, \$350 each additional day.

- St Kitts \& Nevis -- \$350 first day, \$350 each additional day.

- St Vincent \& Grenadines -- \$350 first day, $\$ 350$ each additional day.

For more information on these services, please contact doreen.weekes@ NOSPAM.mail.doc.gov or contact your local Export Assistance Center of the U.S. Department of Commerce, the U.S. Commercial Service Caribbean Regional Office in the U.S. Embassy in Santo Domingo (telephone 809-227-2121; fax 809-920-0267), or the U.S. Commercial Service in the U.S. Embassy in Bridgetown (telephone 246-436-4950, extension 2240; fax 246-228-6084) to find out how to order the service(s).

\section{Direct Marketing}

Direct marketing is not common in Barbados, although Avon has established a successful foreign-owned marketing organization here. The Barbados Investment and Development Corporation (BIDC) can be helpful in arranging this type of activity. 


\section{Franchising}

The Barbados Minister of Finance and Economic Affairs evaluates the potential competitive impact on non-franchised local businesses and must approve all franchises. Franchise holders pay an initial registration fee of US\$5,000 and annual renewal fees of US $\$ 1,000$. All franchises must be registered with the Ministry of Finance to operate legally and repatriate profits and capital. Process franchises, such as those used in manufacturing or designs, must also be registered so that royalties can be remitted abroad. Barbados currently has a policy of refusing to grant franchise applications to foreign fast-food franchises.

\section{Joint Ventures / Licensing}

There is considerable joint venture and licensing activity in Barbados. The BIDC can also be helpful in arranging this type of activity.

\section{Selling Factors / Techniques}

In sales of services and manufactured goods, Barbadians prefer to buy proven and brand name goods. Because prices are high and storage space may be limited, Barbadians tend to purchase smaller lots of consumer goods more often than is the norm in larger countries.

\section{Advertising / Trade Promotion}

Most businesses advertise in newspapers or on radio; the one local television station does not have programming in the morning hours but has started a print ad service on television (texts and telephone numbers appear on the screen). Local access to American channels via local cable is widespread and increasing.

\section{Product Pricing}

Prices in Barbados are high, typically twice what a product would cost in the United States. Import tariffs and taxes are high, and competition at the wholesale and retail level is minimal. Barbadians are accustomed to paying exceptionally high prices locally and frequently make shopping trips to San Juan, New York, and Miami. The large difference in prices has led to the creation of a "barrel industry" whereby individuals ship large barrels of consumer goods to Barbados and other Eastern Caribbean islands by sea as a means of reducing local spending.

Local companies adopt the cost plus method for pricing of their products. The cost base is the CIF plus local charges. Markups generally range from $20 \%$ to $50 \%$. Higher markups exist for specialty items where there is little or no competition.

\section{Selling to the Government}

Significant opportunities exist for selling to the government. This is particularly the case when project financing is available from international financial institutions or from foreign government aid sources that do not require purchase from donor country companies.

\section{IPR Infringement Protection}

Barbados is committed to providing world standard IPR (Intellectual Property Right) protection to all investors. The government of Barbados adopted a new Copyright Act in August of 1998, and legislation was approved in September of 1998 for Integrated Circuits Topography, Protection against Unfair Competition and Geographical Indications. The Trademark and Industrial Designs Acts were recently revised and now meet world standards. The Agreement on Trade-Related Aspects of Intellectual Property (TRIPS) legislation for Patent and Plant Variety Protection is in an advanced stage. Nonetheless, black market copies of computer software, designer items, and videotapes are easily accessible.

\section{Need for a Local Attorney}

A local attorney is necessary when incorporating and is advised under any circumstance. The Consular Section of the U.S. Embassy in Bridgetown (telephone 246-431-0225; fax 246-431-0179) maintains a current list of lawyers.

\section{Agribusiness Industry Prospects}

Barbados is the eighth largest market in the Caribbean for U.S. agricultural, fish, and forestry products, importing a total of US\$52 million in 2002. In the bulk agricultural category (US\$13.2 million in 2002), the best opportunities for U.S. products 
include soybeans, wheat, coarse grains, and rice. In the intermediate agricultural category (US\$9.3 million in 2002), best market prospects include the sugar, sweeteners, and beverage-base category and the vegetable oils category. Forest products (US\$11.4 million in 2002), are also an important category, with opportunities in softwood, treated lumber, and panel products.

However, the largest of all categories is the consumer-oriented products category (including seafood), which reached US\$17.5 million in 2002. Despite some of the more restrictive import policies in the Caribbean, consumer-oriented goods offer many opportunities for U.S. exporters. Some poultry, pork, ice cream, and other products produced or processed in Barbados are protected with high tariffs. However, the industries cannot meet the full range and quantity of products demanded by the local population. In addition to the local population, a thriving tourism sector further fuels the demand for U.S. food products, particularly U.S. food snacks, eggs and egg products, processed fruits and vegetables, red meats, dairy products, and pet foods.

\section{Trade Regulations and Standards}

\section{Trade Barriers}

Barbados requires importers to obtain licenses, permits, or permission from the proper authorities for specific products prior to importation. Phytosanitary certificates are required from the exporting authorities for fresh fruits, vegetables, plants, and plant materials, and must accompany the goods declaration before processing is allowed. Similarly, overseas health certificates must accompany meat and meat products. Psychotropic and other controlled drugs are subject to licenses from the Ministry of Health. Additionally, there are a number of other products that must meet obligatory requirements form the Barbados National Standards Institution.

Barbados, as a member of the Caribbean Common Market (CARICOM), has implemented CARICOM's Common External Tariff for goods, with import duties ranging from $0 \%$ to $20 \%$.

\section{Customs Valuation}

Values for Customs purposes are based on a CIF basis and commercial invoices are required. Barbados has also implemented the World Trade Organization (WTO ) Valuation Agreement.

\section{Standards}

Importing goods that meet U.S. or European standards is rarely a problem. A number of local companies have successfully completed the ISO 9000 certification process. Others are in the process of working towards certification.

\section{Temporary Entry Provisions}

Most goods can be brought temporarily into Barbados, though they must be registered with Customs at the port of entry. A bond may be required to ensure re-export of the goods.

\section{Import Controls}

Barbados has eliminated restrictive licensing procedures and imposed WTO-approved bound duty rates. However, licenses are still required (automatically granted). A complete list of items that require an import license can be found in a publication titled "Open Import General License Regulation 1995", which can be obtained from the Government Printery (telephone 246-436-6776). Importers must obtain licenses prior to the importation of the goods. Goods subject to bound duty rates can be found on the Customs Tariff (Amendment) Order, 2000 S.I. 2000 No. 29.

Almost all goods can be imported into Barbados, though some require import licenses, including many agricultural products. Beer, fruit juices and fruit drinks can be imported with a license.

Below are some of the documents that must be presented to Customs when goods arrive in Barbados:

- Airway bills or bills of lading, depending on the method of import.

- The CARICOM document invoice (the Commercial Invoice is acceptable if all of the required information is present). 
- The supplier's invoice documenting all items in the shipment.

- The C-60 form (a declaration of particulars relating to Customs value).

- The C-63 form (indicating the items being shipped, the weight, the shipper, the tariff code, etc.).

\section{Export Controls}

There are no significant export controls. The C-63 (indicating the items being shipped, the weight, the shipper, the tariff code, etc.).is used for exports as well as imports. The Commercial Invoice and the relevant Central Bank forms must be presented to Customs. A registered Customs broker is recommended when preparing export and/or import documents.

\section{Free Trade Zones / Warehouses}

There are no free trade zones in Barbados. The government permits goods to be stored in licensed bonded warehouses with duties payable prior to the removal of goods for home consumption.

Information on Customs can be obtained from the following address : Her Majesty's Customs, Captain Randolph Straughan, The Comptroller of Customs, Port Authority Building, Harbour Road, St. Michael, Barbados (telephone 246-430-2310; fax: 246-430-2370).

\section{Membership in Free Trade Agreements}

Most products manufactured in Barbados are eligible for duty-free and quota-free entry to major world markets:

- Under the Caribbean Basin Initiativae (CBI) and the General System of Preferences (GSP), many products made in Barbados enter the United States duty-free provided one of either two requirements are met: at least $35 \%$ of the product's value originated in Barbados, or at least $20 \%$ of the product's value originated in Barbados if not less than $15 \%$ originated in the United States or Puerto Rico. In June of 2001, Barbados fulfilled the requirements for the preferences under the Caribbean Basin Economic Recovery Act (CBERA, or CBI
Enhancement), which provides that additional products will be allowed to enter the United States duty-free.

- Under CARIBCAN, products manufactured or assembled in Barbados can be exported to Canada free of duty if at least $60 \%$ of the ex-factory price of the product originated in Barbados or Canada.

- Under the Cotonou Agreement (the successor to the Lome IV Convention), certain products meeting specified rules of origin can be shipped to countries of the European Union and their overseas departments free of duty.

- As a member of the Caribbean Community and Common Market (CARICOM), products manufactured in Barbados can be exported free of Customs duties to the markets of other CARICOM states if the products are wholly produced in Barbados and meet a minimum value-added criterion or a change in Customs classification.

- Under a CARICOM-Venezuela agreement, Barbadian-manufactured products can be exported to Venezuela duty-free if at least $50 \%$ of their value is local value-added or if the final product is classified under a different tariff heading than any of the material inputs.

- CARICOM signed a trade agreement with Colombia that allows duty-free treatment into Colombia of a list of goods that comprised $86 \%$ of CARICOM's exports to Colombia (in a particular base year). Tariffs on goods accounting for another $4 \%$ of exports to Columbia are gradually being eliminated. The agreement with Colombia has a $40 \%$ regional content rule of origin.

- CARICOM countries approved two protocols in 2001 to amend the CARICOM-Cuba Trade and Economic Cooperation Agreement to allow CARICOM countries to export duty-free and promote trade, investment, cooperation in certain sectors, and the consultation and coordination on issues of mutual interest. 
- CARICOM and the Dominican Republic have a trade agreement allowing duty-free entry for $90 \%$ of goods traded and reduced rates of duty on select goods until 2004.

- Barbados is also a member of the General Agreement on Tariffs and Trade (1947) and has signed and is in the process of implementing all provisions of the World Trade Organization (1994).

\section{Investment Climate in Brief}

- Foreign direct investment in Barbados is strongly encouraged through the Barbados Investment and Development Corporation (BIDC).

- In 2002, the International Financial Services Act was enacted to meet international standards in terms of supervision and regulation of financial institutions, enforcement, and e-commerce.

- Legislation passed in December of 2001 opened telecom to competition and, in March of 2003, the government decided to award new cellular licenses.

- The court systems and police are unbiased and efficient, and the government operates in an essentially transparent manner.

- Property rights are protected in Barbados.

- There are no free ports or foreign trade zones in Barbados.

- Programs offered by the BIDC for both locallyand foreign- owned companies:

- The Training Grant Scheme partially reimburses training costs at the time of company start-up.

- The Export Grant and Incentive Scheme helps defray export costs.

- The Technical Assistance Program helps companies solve a variety of problems.
- Corruption is not a significant problem in Barbados.

- Barbados enjoys a relatively tranquil labor environment.

- The Securities Exchange of Barbados was established in 1997 to help companies raise capital and to assist with privatization efforts.

- Capital and profits from foreign direct investment may be repatriated if the investment was registered with the Central Bank at the time the investment was made.

- There is no record of outstanding expropriation claims.

- Disputes between the United States and Barbados fall under the jurisdiction of the World Trade Organization.

- There is no political violence in Barbados.

- There are no performance incentives or requirements in Barbados.

- There is no bilateral investment treaty between Barbados and the United States.

- The Barbadian dollar is pegged to the U.S. dollar at a rate of two Barbados dollars to one U.S. dollar.

\section{Business Customs}

\section{Travel Advisory and Visas}

No travel advisories are in effect. Visas are not necessary for U.S. citizens carrying U.S. passports. American citizens traveling direct from the United States to Barbados may be admitted without a passport for a period not exceeding three months, as long as they present photo identification establishing their identity and nationality, along with a valid return ticket. However, U.S. citizens may find it easier to re-enter the United States if they carry a valid passport. Barbados collects a departure tax of BDS\$25 (US\$13). 


\section{Business Infrastructure}

Barbadian men may wear a "shirt-jack", which is similar to a short-sleeved, safari-type jacket with matching trousers. Normal business attire for Non-Barbadian men is a suit and tie. Women should wear a short- or long-sleeved suit or dress. Business hours are typically from 8:00 a.m. to 4:30 p.m. Luncheon meetings are more common than breakfast meetings. Appointments are normally required for business meetings.

Several U.S. and regional commercial airlines fly directly to San Juan, Miami, Philadelphia, Washington, D.C., and New York. US Airways recently started daily, non-stop flights to Philadelphia, and American/American Eagle and British West Indies Airways also operate direct service to the United States. Canadian and British airlines fly direct service to those countries, and Caribbean-based air carriers provide frequent service to the rest of the Caribbean and to Venezuela.

American business travelers are encouraged to visit the U.S. Department of State's website for up-to-date travel warnings and information at http://travel.state.gov. Information on key officers at Foreign Service Posts is also available online at http://fola.state.gov/MMS/KOH/keyofficers.asp. Further, country-specific information is available at http://www.state.gov/p.wha/pl.

Business Travelers to Barbados seeking appointments with U.S. Embassy Bridgetown Commercial Service officials should contact the Commercial Section in advance of their travel (telephone 246-436-4950, extension 2240; fax 246-228-6084; e-mail doreen.weekes@ mail.doc.gov.

\section{Useful Web Sites}

\section{BARBADOS:}

- Barbados Statistical Services http://www.bgis.gov.bb/stats

- Government of Barbados Information Network http://www.barbados.gov/bb

- Barbados Chamber of Commerce http://www.bdscham.com
- Barbados Port Authority http://www.barbadosport.com

\section{UNITED STATES:}

- USDA Foreign Agricultural Service http://www.fas.usda.gov

- US Export Programs Guide http://infoserv2.ita.doc.gov/ticwebsite/tic.nsf/ AF34FA880278BDD5825690D00656C6F/ F69FDCF72B7713B58525691900746F18?Open Document

- Internet Guide to Trade Leads http://infoserv2.ita.doc/gov/ticwebsite/tic.nsf/ 504ca249c786e20f85256284006da7ab/ ef7db94aef24919885266470049c1cd?OpenDocu ment

- US Trade Finance Resources http://infoserv2.ita.doc.gov/ticwebsite/tic.nsf/ AF34FA880278BDD5825690D00656C6F/ F69FDCF72B7713B58525691900746F18?Open Document

- Basic Guide to Exporting http://www.unzco.com/basicguide/index.html

\section{HEMISPHERIC:}

- Hemispheric Guide on Customs Procedures http://alca-ftaa.iadb.org/hgcp_eng.htm

- Hemispheric Trade and Tariff Database http://alca-ftaa.iadb.org/eng/ngmadb_e.htm 